\title{
INVESTIGATION OF THE CORRELATION BETWEEN SECONDARY SCHOOL STUDENTS' METACOGNITIVE AWARENESS LEVEL AND LISTENING-MONITORING STRATEGIES
}

\author{
Gürbüz Ocak, \\ Burak Oluri, \\ Tuğçe Zehra Kızılgöl \\ Afyon Kocatepe University, \\ Turkey
}

\begin{abstract}
:
The aim of this study is to determine the correlation between secondary school students' metacognitive awareness levels and frequency of listening / monitoring strategies. In the study, correlational survey model has been employed. The sample of the study consists of 406 secondary school students from 4 schools determined by criterion sampling method in the 2018-2019 academic year. The Metacognitive Awareness Inventory for Children (Jr. MAI) - A and B Forms and The Usage Frequency Scale of Listening/Monitoring Strategies in Secondary School Students have been used as data collection tools. Percentage, frequency, arithmetic mean, correlation analysis, t test, twoway ANOVA analysis have been used. As a result of the research, it has been found out that the frequency of using secondary school students' listening / monitoring strategies is high, and there is a positive correlation between metacognitive awareness level and listening / monitoring strategies. Furthermore, it has been concluded that there is a significant correlation between the metacognitive awareness levels of the secondary school students and the frequency of using listening / monitoring strategies in terms of grade level, there is a positive correlation in favor of female students in terms of gender variable. According to the results of two-way ANOVA, it has been concluded that there is no significant difference depending on the common effect in problem situations involving gender and class variables.
\end{abstract}

Keywords: listening / monitoring strategies, metacognitive awareness, strategy

i Correspondence: email burakolur@gmail.com 


\section{Introduction}

Rapid development and transformation in technology has brought $\mathrm{Z}$ generation definition to the literature. With the $Z$ generation, which was born in a time period in which digital and high technology is widely used, individuals become more receiverlistener (Şahin, 2017, p.186; Taş, Demirdöğmez and Küçükoğlu, 2017, p.1033). This process negatively affects the development of listening / monitoring skills, depending on how many different variables affect the listening / monitoring process of individuals. Individuals go out of the area where they are actively located in the communication process and get into the passivation process. This situation affects the communication process and indirectly the learning process and prevents the achievement of the desired level of success.

Listening is of great importance in terms of both educational and social relations (Fidan, 2019, p.80). The ability to listen / monitor, which has an important effect on the communication and learning experiences of the individual, is defined as the reaction to the visual and auditory symbols. The fact that it is the very first skill an individual gain and the acquisition of most of the learning through the listening / monitoring process reveals the importance of this skill domain. It is also known that it has a direct effect on speaking, reading and writing skill, which are among the basic skill domains. In order for individuals to develop at the desired level in the fields of speaking, reading and writing, their listening / monitoring skills must be developed. For this reason, individuals should develop their listening / monitoring skills with a conscious process (Birol \& Ergin, 2000, p.113; Deniz and Dinçel, 2015, p.17; Emiroğlu \& Pınar, 2013, p.770).

One of the main factors of the problems encountered during the listening / monitoring process is that it is not known that listening and hearing processes are different. According to Melanlığlu (2012, p.67), mixing the listening process, which are described as giving full attention to what is said and understanding them, and hearing processes, negatively affects the development of listening skill and causes not to be given importance. Hearing process, which emerges as a physiological process, occurs when the sound waves are transmitted from the outer ear to the eardrum, and the mechanical vibrations in the middle ear turn into nerve currents going to the brain in the inner ear, and listening appears at the end of a psychological process (Birol and Ergin, 2000, p.114). The problems encountered in making this distinction between listening and hearing processes prevents the individual from raising awareness, and because it sees the listening process as a spontaneous process, it does not support its development. Therefore, first of all, individuals should be supported to develop awareness by supporting the skills of conducting, monitoring and evaluating the process, namely metacognitive skills.

Metacognition, emphasizing its importance on listening, can be defined as "awareness of one's own cognitive processes". The listening / monitoring process emerges as a process that only the individual can control. For this reason, the individual should be made aware of this process by using metacognitive strategies. On the basis of the 
metacognitive awareness understanding; There are concepts of being aware of the person's self and learning ways, acting consciously, self-control, self-regulation and selfevaluation, planning, monitoring how one learns and learning to learn (Akkurt, 2018, p.19-20).

Akın (2006, p.43; cited in Katranc1 \& Yang1n, 2013, p.738) stated that students can use their questions such as 'What do I know about the topic I'm listening to? Do I know what I need? How much time will I need to listen to this text? What listening strategies can I use while listening to this text? Did I understand what I saw and listened to? How can I recognize if I make a mistake in the listening process? If my plan is not enough to achieve my goal, how can I renew it? How can I measure my success?' and similar questions in their own development process in order to improve their metacognitive awareness level. Teachers, on the other hand, should focus on activities that will develop listening / monitoring strategies and students should be supported in listening / monitoring and other basic skill areas by using different strategies, methods and techniques in the classroom. Thus, there will be an opportunity to overcome the difficulties experienced in processes such as understanding, perception, thinking, remembering in education (Karakelle \& Saraç, 2007, p.88-89; Şahin, 2017, p.185).

For the development of the aforementioned skills, students should be supported by effective teacher and family guidance. For this, first of all, parents and teachers should have information about the process. When the literature is examined, it is seen that there are very few studies directly examining the relationship between secondary school students' metacognitive awareness levels and their frequency of using listening / monitoring strategies. Listening / monitoring is the basic element of communication and learning (Deniz \& Dinçel, 2015, p.17). Although it is the first acquired and most used skill area, due to its abstract structure and mixing with the hearing process, the necessary importance is not given and its effect on student achievement is neglected. It is known that students will have more successful learning processes by considering the variables that affect the listening / monitoring processes. For this reason, it is thought that 'metacognitive awareness level', which is thought to be effective on students' listening / monitoring strategies, is important in terms of determining the effect of 'frequency of listening / monitoring strategies' and revealing the of the relationship between them. Accordingly, it is expected that the study will contribute to the awareness students' frequency of using listening / monitoring strategies.

\section{The Purpose of the Study}

It is aimed to determine the correlation between the frequency of secondary school students' use of listening-monitoring strategies and their metacognitive awareness levels.

\subsection{The Research Problems}

1) What is the current situation of secondary school students' use of listening / monitoring strategies? 
2) What is the current situation of secondary school students' metacognitive awareness levels?

3) Is there a statistically significant correlation between secondary school students' metacognitive awareness levels and their frequency of using listening / monitoring strategies?

4) Is there a statistically significant correlation between secondary school students' metacognitive awareness levels and their frequency of using listening / monitoring strategies in terms of gender variable?

5) Is there a statistically significant relationship between secondary school students' metacognitive awareness levels and their frequency of using listening / monitoring strategies in terms of grade level?

6) Do secondary school students' metacognitive awareness levels predict their listening /monitoring levels?

7) Is there a common effect of the following variables on secondary school students' listening / monitoring levels?

a) Their metacognitive awareness level and gender

b) Their metacognitive awareness level and grade level

\section{Method}

This research, which has been carried out according to the quantitative research method, has been designed in the correlational survey model. Survey models provide the quantitative or numerical description of trends, attitudes or views through studies on a sample selected from a universe. Thus, the researcher makes inferences about the universe obtained from the sample (Creswell, 2017; Translation edt, Demir).

\subsection{Sample of the Study}

The population of the study consists of 5,000 secondary school students studying in 5th, 6th, 7th and 8th grades in the public school in Afyonkarahisar city center. Due to the large population of the study, sampling method has been used and cluster sampling method has been preferred. The cluster sampling method consists of two stages. For this reason, in the first stage, schools were selected with the simple random sampling method, and in the second stage, the classes were chosen neutrally. The sample of the study consists of 406 secondary students. The demographic information of the sample has been given in the Table 1.

Table 1: The Demographic Information of the Sample

\begin{tabular}{lcccccc}
\hline Gender & $\mathbf{f} / \mathbf{\%}$ & \multicolumn{3}{c}{ Grade Level } & Total \\
\hline \multirow{2}{*}{ Female } & & $5^{\text {th }}$ & $6^{\text {th }}$ & $7^{\text {tht }}$ & $8^{\text {th }}$ & \\
\cline { 3 - 7 } & $\mathbf{f}$ & 25 & 74 & 79 & 42 & 220 \\
\cline { 3 - 7 } Male & $\mathbf{\%}$ & 11.4 & 33.6 & 35.9 & 19.1 & 100.0 \\
\hline & $\mathbf{f}$ & 30 & 54 & 63 & 39 & 186 \\
\hline
\end{tabular}


When Table 1 is examined, it is seen that there are 220 female and 186 male students in the study group participating in the study; 25 girls and 30 boys in the 5 th grade; 74 girls and 54 boys in the 6th grade; 79 girls and 63 boys in the 7 th grade; 42 female and 39 male students in the 8th grade.

\subsection{Data Collection Tools}

Two different scales have been used to gather data in the study. The data collection tools have been given in this section.

\subsubsection{The Usage Frequency Scale of Listening/Monitoring Strategies in Secondary School Students}

It is aimed to reveal the factors that affect the frequency of secondary school students' use of listening / monitoring strategies with this measurement tool. The scale is in five-point likert type and includes "never (1), rarely (2), occasionally (3), usually (4) and always (5)" intervals.

The scale consists of 3 sub-dimensions and 19 items. the Cronbach Alpha coefficient for the scale is .89. The Cronbach Alpha of the first factor is .728, the second factor is .838 and the third one is .766 (Doğan \& Erdem, 2017). It can be said that it is a reliable scale since it is larger than .70 (Pallant, 2007, as cited in Doğan \& Erdem, 2017).

\subsubsection{The Metacognitive Awareness Inventory for Children (Jr. MAI)- A and B Forms}

It was aimed to determine the metacognitive awareness levels of secondary school students with this measurement tool developed by Speling, Howard, Miller and Murphy (2002) and adapyed into Turkish by Karakelle and Saraç (2007). The scale is in five-point likert type and includes "never (1), rarely (2), sometimes (3), often (4) and always (5)" intervals. The scale consists of 18 items (the Cronbach Alpha coefficient is .80). The scale consists of two forms as A and B. In this study, the B form has been used as to measure metacognition level.

\subsection{Analysis of the Data}

The data is examined by normality test. According to the skewness and kurtosis values, Frequencies and percentages, simple linear correlation, simple regression and two-way ANOVA have been employed in the study.

\section{Findings}

Finding related to the sub-problems of the study are given below.

The finding of the first sub-problem of the study 'What is the current situation of secondary school students' use of listening / monitoring strategies?' is given in Table 2. 
Table 2: Descriptive statistics on the usage frequency scale of listening/monitoring strategies in secondary school students

\begin{tabular}{lcc}
\hline Scale and Sub-scales & $\mathbf{x}$ & ss \\
\hline Critical Listening / Monitoring & 3.73 & 0.846 \\
\hline Comprehensive Listening / Monitoring & 3.52 & 0.953 \\
\hline Distinctive Listening / Monitoring & 3.80 & 0.955 \\
\hline Scale Total & 3.66 & 0.818 \\
\hline
\end{tabular}

As can be seen in Table 2, the mean value of the secondary school students regarding the use of listening and monitoring strategies is at the level of 'usually' $(\bar{x}=3.66)$. The mean values of the sub-scales are that critical listening / monitoring is at the level of 'usually'

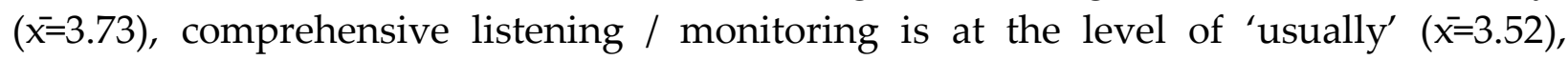
distinctive listening / monitoring is at the level of 'usually' ( $\bar{x}=3.80)$.

The finding of the second sub-problem of the study 'What is the current situation of secondary school students' metacognitive awareness levels?' is given in Table 3.

Table 3: Descriptive statistics the metacognitive awareness inventory for children (Jr. MAI)- A and B forms

\begin{tabular}{lcc}
\hline Scale and Sub Scales & $\overline{\mathbf{x}}$ & ss \\
\hline Scale Total & 3.78 & 0.652 \\
\hline
\end{tabular}

As can be seen in Table 3, the mean value of the secondary school students regarding the metacognitive awareness level is at the level of 'usually' $(\bar{x}=3.78)$.

The finding of the third sub-problem of the study 'Is there a statistically significant correlation between secondary school students' metacognitive awareness levels and their frequency of using listening / monitoring strategies?' is given in Table 4.

Table 4: The correlation between listening/monitoring strategies and the metacognitive awareness

\begin{tabular}{lcc}
\hline & Correlation Coefficient & \\
& $(\mathbf{r})$ & $\mathbf{p}$ \\
\hline $\begin{array}{l}\text { Listening/monitoring strategies } \\
\text { Metacognitive awareness }\end{array}$ & .406 & $.000^{*}$ \\
\hline
\end{tabular}

As can be seen in the Table 4 which shows the results of the simple linear analysis carried out to see if there was a statistically significant correlation between listening / monitoring strategies and metacognitive awareness reveals that there is a significant $(\mathrm{p}<.05)$, moderate and positive sided $(\mathrm{r}=.406)$ correlation between two variables.

The finding of the fourth sub-problem of the study 'Is there a statistically significant correlation between secondary school students' metacognitive awareness levels and their frequency of using listening / monitoring strategies in terms of gender variable?' is given in Table 5. 
Table 5: The correlation between listening/monitoring strategies and the metacognitive awareness in terms of gender variable

\begin{tabular}{lllll}
\hline Gender & Variables & r & p \\
\hline \multirow{2}{*}{ Female } & Listening/monitoring strategies & \multirow{2}{*}{.753} & .000 \\
\cline { 2 - 2 } Male & Metacognitive awareness & \multirow{2}{*}{.707} & .000 \\
\cline { 2 - 3 } & Listening/monitoring strategies & Metacognitive awareness & & \\
\hline
\end{tabular}

As seen in the Table 5, there is a significant, high and positive sided correlation between two variables in terms of gender variable: both for female $(r=.753, p<.05)$ and male $(r=.707$, $\mathrm{p}<.05)$.

The finding of the fifth sub-problem of the study 'Is there a statistically significant relationship between secondary school students' metacognitive awareness levels and their frequency of using listening / monitoring strategies in terms of grade level?' is given in Table 6.

Table 6: The correlation between listening/monitoring strategies and the metacognitive awareness in terms of grade level variable

\begin{tabular}{|c|c|c|c|}
\hline Grade Level & Variables & $\mathbf{r}$ & $\mathrm{p}$ \\
\hline \multirow{2}{*}{$5^{\text {th }}$} & Listening/monitoring strategies & \multirow{2}{*}{.853} & \multirow{2}{*}{.000} \\
\hline & Metacognitive awareness & & \\
\hline \multirow{2}{*}{$6^{\text {th }}$} & Listening/monitoring strategies & \multirow{2}{*}{.730} & \multirow{2}{*}{.000} \\
\hline & Metacognitive awareness & & \\
\hline \multirow{2}{*}{$7^{\text {th }}$} & Listening/monitoring strategies & \multirow{2}{*}{.717} & \multirow{2}{*}{.000} \\
\hline & Metacognitive awareness & & \\
\hline \multirow{2}{*}{$8^{\text {th }}$} & Listening/monitoring strategies & \multirow{2}{*}{.690} & \multirow{2}{*}{.000} \\
\hline & Metacognitive awareness & & \\
\hline
\end{tabular}

As seen in the Table 6, there is a significant, high and positive sided correlation between two variables in terms of grade level variables in $6^{\text {th }}$ grade $(\mathrm{r}=.730, \mathrm{p}<.05), 7^{\text {th }}$ grade $(\mathrm{r}=$ $.717, \mathrm{p}<.05), 8^{\text {th }}$ grade $(\mathrm{r}=.690, \mathrm{p}<.05)$, and very high and positive sided correlation in $5^{\text {th }}$ grade $(\mathrm{r}=.853, \mathrm{p}<.05)$.

The finding of the sixth sub-problem of the study 'Is there a common effect of the metacognitive awareness and gender and metacognitive awareness level and grade level on secondary school students' listening / monitoring levels?' is given in Table 7.

Table 7: Common effect of the metacognitive awareness level and the variables on secondary school students' listening / monitoring levels

\begin{tabular}{lcccc}
\hline Variables & Sum of Squares & Mean Square & $\mathbf{F}$ & $\mathbf{p}$ \\
\hline Metacognitve awareness level ${ }^{*}$ gender & 13,992 & 0,333 & 1,17 & .232 \\
\hline Metacognitve awareness level ${ }^{*}$ grade & 28,21 & 0,294 & 1,02 & 0,44 \\
\hline
\end{tabular}

As given in the Table 7, neither metacognitive awareness level and gender nor metacognitive awareness level and grade have a common effect on secondary school students' listening / monitoring levels ( $\mathrm{p}>$.05). 


\section{Results and Discussion}

The purpose of this study is to determine the correlation between secondary school students' metacognitive awareness levels and frequency of listening / monitoring strategies. When the data have been examined, it has been concluded that the frequency of use of listening / monitoring strategies is high among the secondary students. The students got the highest point from 'Distinctive Listening / Monitoring' $(\bar{x}=3,80)$ and this is followed by 'Critical Listening /Monitoring' $(\bar{x}=3,72)$ and 'Comprehensive Listening / Monitoring' $(\bar{x}=3,52)$. Even the fact that the students have got high points from the subscales of listening/monitoring strategies, these strategies should be supported to increase the awareness of the students. The students should know 'Why do they listen?' before they start to listen. A child should know that why she/he will listen something to be able to determine the details and main idea, to distinguish the facts from fiction, etc. before start listening (Funk ve Funk, 1989; cited in Doğan, 2008). It does not seem possible to achieve the desired success at gaining basic listening / monitoring skills and developing areas that are lacking with a study whose purpose is not determined. For this reason, as Şahin (2017) stated, studies related to the listening process should be focused on and necessary measures should be taken in order to make the process more active.

When the correlation between the metacognitive awareness levels of the secondary school students and the frequency of using listening / monitoring strategies has been examined, it has been reached that there is a positive significant relationship between their metacognitive awareness levels and the frequency of using listening / monitoring strategies. In the studies conducted by Melanlığlu (2011) and Katrancı and Yangin (2013), it has been concluded that the level of metacognitive awareness positively affected the listening / monitoring process. When the correlation between the metacognitive awareness levels of the secondary school students and the frequency of using listening / monitoring strategies has been examined in terms of gender variable, it has been concluded that there is very high, positive sided significant correlation between two variables in terms of gender variable. Moreover, the correlation between two variables is relatively higher among female students.

When the correlation between the metacognitive awareness levels of the secondary school students and the frequency of using listening / monitoring strategies has been examined in terms of grade variable, it has been concluded that there is very high, positive sided significant correlation between two variables in terms of grade variable. It has been found that 5 th grade students have the highest level correlation between their metacognitive awareness levels and the frequency of using listening / monitoring strategies. It has been also concluded that as the class level increases, the level of correlation decreases. Similarly, in the study conducted by Demircan and Aydin (2019) in order to examine the listening / monitoring self-efficacy, it was found that as the grade level increased, the listening self-efficacy decreased. The reason for this situation may be that teachers include traditional teaching methods and techniques in classrooms and do not create any opportunities to improve students' listening / monitoring and higher 
cognitive awareness levels. Furthermore, while the skill development of students should increase during the learning-teaching processes, it is seen that they are dulled by the wrong learning-teaching processes. In order to get this situation better, students should get education which will enable them to use listening / monitoring strategies and develop a positive attitude about listening / monitoring, and variables that affect the listening / monitoring process should be taken into account. Thus, it is necessary to teach the students how they will listen; what they will do before listening, during listening and after listening; how they will check whether they understand or not what they listen; how they will make the required correction (Melanlığlu, 2012; Karakoç- Öztürk, 2017).

When the common effect of metacognitive awareness level and gender on the frequency of using listening / monitoring strategies has been examined, it has been found that the level of metacognitive awareness and gender do not have a significant effect on the frequency of using listening / monitoring strategies. When the common effect of metacognitive awareness level and grade level on the frequency of using listening / monitoring strategies has been examined, it has been concluded that the level of metacognitive awareness and gender do not have a significant effect on the frequency of using listening / monitoring strategies, as well.

In line with the results of the research, it is seen that the metacognitive awareness level is effective on the frequency of use of listening / monitoring strategies. This situation reveals the necessity of supporting the development of metacognitive awareness level in order to develop listening / monitoring skills. The fact that the correlation level decreases as the grade level increases reveals that the intended purpose of the education cannot be reached. As the grade levels of the secondary school students increase, the decrease in the level of cognition and listening / monitoring shows that the intended goals cannot be achieved. Therefore, individuals are expected to have metacognitive skills and awareness, and as a result, to use learning strategies as stated in Sarıkahya (2017). Therefore, teaching strategies should be developed to provide metacognition in curriculum. For this reason, firstly, curriculum should be organized, the awareness levels of teachers should be increased, and students should be supported until they reach the targeted development level by getting rid of their passive positions.

Studies can be organized to raise the awareness of students so that they can develop listening / monitoring strategies. By organizing activities in the classroom, interactions can be created by which students can improve their listening / monitoring skills. In-service trainings can be organized so that teachers can get more comprehensive information about students' basic skills and put them into practice. Listening / monitoring includes a comprehensive process and is affected by many variables. For this reason, it can be supported with more qualitative researches in order to obtain more comprehensive information about the variables that affect the listening / monitoring process. Consequently, considering the research results, it can be suggested to determine the frequency of listening / monitoring and metacognitive awareness levels of the secondary school students and use them in teaching. 


\section{References}

Akkurt, N. D. (2018). Üstbiliş stratejileri öğretiminin çevre duyarlılı̆̆ına etkisi. Uluslararası Türk Kültür Coğrafyasında Sosyal Bilimler Dergisi (TURKSOSBİLDER), 3(1), S. 16-25.

Büyüköztürk Ş., Çakmak, E. K., Akgün, Ö. A., Karadeniz, Ş., Demirel, F. (2011). Bilimsel araştırma yöntemleri. Ankara: Pegem Akademi.

Can, A. (2018). SPSS ile bilimsel araştırma sürecinde nicel veri analizi. Ankara: Pegem Akademi.

Creswell, J. W. (2017). Araştırma deseni: nitel, nicel ve karma yöntem yaklaşımları. (Demir, S. B., Çev. ED.). Ankara: Eğiten Kitap.

Demircan, U. \& Aydın İ. S. (2019). Ortaokul öğrencilerinin dinleme/izleme özyeterliklerinin çeşitli değişkenlere göre incelenmesi. Kastamonu Ĕ̆itim Dergisi, 27(4), S. 1517-1527.

Deniz, K. \& Dinçel, B. K. (2015). Anlama becerilerine yönelik ölçme ve değerlendirme araştırmalarının incelenmesi. Mustafa Kemal Üniversitesi Sosyal Bilimler Enstitüsü Dergisi, 12 (29), S.16-46.

Doğan, Y. (2008). İlköğretim 7. Sınıf öğrencilerinin dinleme becerisini geliştirmede etkinlik temelli çalışmaların etkililiği. Türk Eğitim Bilimleri Dergisi, 6(2), S.261-286.

Doğan, B. Ve Erdem, İ. (2017). Ortaokul öğrencilerinin dinleme/izleme stratejileri kullanım sıklığı ölçeğinin geçerlik-güvenirlik çalışması. E-Uluslararası Ĕ̆̈itim Araştırmaları Dergisi, 8(1), S. 64-81.

Emiroğlu, S. \& Pınar, F. N. (2013). Dinleme becerilerinin diğer beceri alanları ile ilişkisi. Turkish Studies, 8(4), S. 769-782.

Ergin, A. ve Birol, C. (2000). Eğitimde iletişim. Ankara: Anı Yayıncılık

Fidan, M. (2019). Ortaokul öğrencilerinin Türkçe dersinde kullandıkları eleştirel dinleme stratejilerinin çeşitli değişkenler yönünden incelenmesi. Rumelide Dil ve Edebiyat Araştırmaları Dergisi, (15), 79-98.

Glıner, J. A., Morgan, G. A., \& Leech, N. L. (2015). Uygulamada araştırma yöntemleri desen ve analizi bütünleştiren yaklaşım. (Turan, S., Çev.). Ankara: Nobel.

Katrancı ve Yangın, (2013). Üstbiliş stratejileri öğretiminin dinlediğini anlama becerisine ve dinlemeye yönelik tutuma etkisi. Adıyaman Üniversitesi Sosyal Bilimler Enstitüsü Dergisi Türkçenin Ĕ̆itimi Öğretimi Özel Sayısı, 6(11), S. 734-771.

Karakoç-Öztürk, B. (2017). Ortaokul öğrencilerinin dinleme becerisine yönelik olarak kullandıkları üstbiliş stratejilerinin belirlenmesi. Eğitimde Kuram ve Uygulama, 13(1), S. 158-182.

Karakelle, S. Ve Saraç, S. (2007). Çocuklar için üst bilişsel farkındalık ölçeği (ÜBFÖ-Ç) A ve B formları: geçerlik ve güvenirlik çalışması. Türk Psikologlar Derneği: Türk Psikoloji Yazıları, 10(20), S. 87-103.

Melanlığlu, D. (2011). Üstbiliş strateji eğitiminin ilköğretim ikinci kademe öğrencilerinin dinleme becerilerine etkisi. (Yayınlanmamış Doktora Tezi). Gazi Üniversitesi Ĕ̆itim Bilimleri Enstitüsü, Ankara. 
Melanlığlu, D. (2012). Dinleme becerisine yönelik ölçme değerlendirme çalışmalarında üstbiliş stratejilerinin kullanımı. Turkish Studies, 7(1), S.1583-1595.

Sarıaslan, H., Karacabey, A. A., Gökgöz, F. (2017). Nicel karar yöntemleri. Ankara: Siyasal Kitabevi.

Sarıkahya, E. (2017). Üst biliş kavramının fen öğretiminde kullanılmasına yönelik yapılmış çalışmaların lisansüstü tezlere dayalı analizi. ESTÜDAM Eğitim Dergisi, 2(1), S. 1-20.

Şahin, A. (2017). İlköğretim 6. Sınıf öğrencilerinin dinleme becerisi farkındalıklarının sosyo-ekonomik düzeye göre incelenmesi. Çankırı Karatekin Üniversitesi Sosyal Bilimler Enstitüsü Dergisi, 2(1), S. 178-188.

Taş, H. Y., Demirdöğmez, M. ve Küçükoğlu, M. (2017). Geleceğimiz olan z kuşağının çalışma hayatına muhtemel etkileri. Uluslararası Toplum Araştırmaları Dergisi, 7(13), S. 1033-1048. 

be applied to their work. Under the terms of this license, no permission is required from the author(s) or publisher for members of the community to copy, distribute, transmit or adapt the article content, providing a proper, prominent and unambiguous attribution to the authors in a manner that makes clear that the materials are being reused under permission of a Creative Commons License. Views, opinions and conclusions expressed in this research article are views, opinions and conclusions of the author(s). Open Access Publishing Group and European Journal of Open Education andE-learning Studies shall not be responsible or answerable for any loss, damage or liability caused in relation to/arising out of conflict of interests, copyright violations and inappropriate or inaccurate use of any kind content related or integrated on the research work. All the published works are meeting the Open Access Publishing requirements and can be freely accessed, shared, modified, distributed and used in educational, commercial and non-commercial purposes under a Creative Commons Attribution 4.0 International License (CC BY 4.0). 